\title{
Seroprevalence of Mycobacterium avium ssp. paratuberculosis in small ruminants in a flock in Antioquia, Colombia
}

\section{Seroprevalencia de Mycobacterium avium subsp. paratuberculosis en pequeños rumiantes de un aprisco de Antioquia, Colombia}

Fecha de recepción: 12 de diciembre de 2016 Fecha de aprobación: 17 de abril de 2017
José Miguel Hernández-Agudelo ${ }^{1}$

Yadi Marcela García-Tamayo² Jorge Arturo Fernández-Silva ${ }^{3}$

DOI: http://doi.org/10.19053/01228420.v14.n2.2017.7148

\begin{abstract}
Paratuberculosis is a chronic infectious disease caused by Mycobacterium avium ssp. paratuberculosis (MAP). This study aimed at determining the presence of antibodies against MAP, and the association between the serological status of MAP and individual factors in goats and sheep in a flock in Antioquia, Colombia. We studied fifty-three goats and 6 sheep over two years old, and took blood samples to obtain serum and information on individual factors. The presence of antibodies against MAP was determined by ELISA, whereas the information was descriptively analyzed. ELISA did not detect any positive or suspect animal among the 59 tested animals, so an association between serological status to MAP and individual factors could not be established. This is the first and the fourth study reporting the search for antibodies against MAP in a goat and in a sheep population in Colombia, respectively. Several factors may explain the serological status of the sampled animals. It is necessary to continue with similar studies in other flocks of the region and the country to determine the current MAP infection status in small ruminants in Colombia.
\end{abstract}

Keywords: Johne's disease; paratuberculosis; small ruminants; weight loss.

1 Universidad de Antioquia (Medellín, Colombia).jmiguel.hernandez@udea.edu.co.

2 Universidad de Antioquia (Medellín, Colombia).

3 Ph. D. Universidad de Antioquia (Medellín, Colombia).jorge.fernandez@udea.edu.co. 


\section{Resumen}

La paratuberculosis es una enfermedad infecciosa crónica causada por Mycobacterium avium subsp. paratuberculosis (MAP). El objetivo de este estudio fue determinar la seroprevalencia de MAP y la asociación existente entre el estatus serológico a MAP y factores individuales en cabras y ovejas de un aprisco en Antioquia, Colombia. Se estudiaron 53 caprinos y 6 ovinos mayores a dos años de edad, de los cuales se tomó información sobre factores individuales y una muestra de sangre para obtener suero sanguíneo. La presencia de anticuerpos contra MAP se determinó por medio de una prueba de ELISA, mientras que la información se analizó descriptivamente. La prueba de ELISA no detectó ningún animal positivo o sospechoso entre los 59 analizados, por lo que no se pudo establecer asociación entre el estatus serológico a MAP y factores individuales. Este es el primer estudio que reporta la búsqueda de anticuerpos contra MAP en una población caprina, y el cuarto en una población ovina en Colombia. Diversos factores pueden explicar el estatus serológico de los animales muestreados. Es necesario continuar con estudios similares en otros apriscos de la región y del país para determinar el estatus real de la infección en pequeños rumiantes en Colombia.

Palabras clave: enfermedad de Johne; paratuberculosis; pequeños rumiantes; perdida de peso.

\section{Como citar:}

Hernández-Agudelo JM., García-Tamayo YM., Fernández-Silva JA. Seroprevalence of Mycobacterium avium ssp. paratuberculosis in small ruminants in a flock in Antioquia, Colombia. Rev. Cien. Agri. 2017; 14(2): 49-58. 


\section{Introduction}

Paratuberculosis, also known as Johne's Disease, is a chronic granulomatous inflammation of the digestive tract caused by the microorganism Mycobacterium avium ssp. paratuberculosis (MAP), which is an intracellular pathogen, acid-fast and facultative bacillus (1). Bovine paratuberculosis is widely distributed around the world, and has been well characterized especially in this species (2). Although it is generally assumed that the disease occurs similarly in all domestic ruminant species, there is sufficient evidence suggesting that paratuberculosis in small ruminants is different from the disease in cattle, both in the clinical form and the involved MAP strains; even among small ruminants, clinical forms and MAP infective strains substantially differ between sheep and goats (3).

In sheep, the clinical signs of paratuberculosis are limited to weight loss $(4,5)$, which may occur starting at two years of age, with most animals between 3 and 5 years old succumbing to the disease (4). Edema can occasionally occur, and in advanced cases animals may have hypoalbuminemia and hypocalcemia (4). Unlike cattle, most of the sheep that die from Johne's Disease have normal fecal material, so diarrhea is not seen as a significant sign of paratuberculosis in small ruminants, except in the terminal stages of the disease (3-6). Paratuberculosis in sheep is widespread and is a serious threat to their production, because it tends to remain hidden, showing only indirect effects in the production (7). Although few studies exist, almost all of them from Australia, they clearly recognize that Johne's Disease in sheep produces serious economic impacts. Two studies in Australia provided, for the first time, objective information on the economic impact of Johne's Disease in sheep, revealing that the average of deaths caused by the disease was $6.2 \%$ of adults in the flock every year, doubling the country's acceptance levels (2-3\%) for all causes. In the same way, death rates in the flocks ranged from 2.1 to $17.5 \%$ per year, being the disease responsible for $69 \%$ of all deaths in the studied farms. Additionally, the studies determined that paratuberculosis infection resulted in an average reduction of $6.4 \%$ in the expected profit mar- gin in each farm, which included the direct costs associated to the disease, such as production costs due to animal death, and the cost of vaccination to reduce the disease transmission (8).

Paratuberculosis in goats is similar to sheep in many aspects (9). During the stage of subclinical disease, goats can become persistent fecal shedders of MAP up to one year post-infection with no clinical signs $(9,10)$. During the clinical disease, the only consistent finding is weight loss, despite an apparent normal feed intake $(5,9)$. Contrary to what has been observed in cattle, diarrhea rarely occurs in goats (5). In this state, the bacterium is detectable in feces and animals usually have antibodies against MAP. If the goats are not previously sacrificed, most animals pass to an advanced clinical disease, in which they develop fragile skin, poor-quality hair, and eventually progressive emaciation, dehydration, anemia, submandibular edema, and depression (9). Paratuberculosis has been a problem in goats, but has received less attention than in other species, probably due to the marginal contributions of its production in countries with a more developed cattle industry (7). Although the precise impact of MAP infection in goats is unknown, is well known that the disease causes considerable economic losses due to reduced feed efficiency, reduced milk production, and culling of infected animals (10). In addition, MAP subclinical infection has resulted in reduced fertility in goats (11). Several risk factors for paratuberculosis in goats have been determined (12). The results of experimental infections found that goats are naturally less resistant to paratuberculosis than cattle or sheep (13).

The Colombian sheep industry has identified some sanitary demands with the objective of developing strategies that allow prevention, control, and treatment of the sanitary problematic in this industry. Specifically, this demand seeks to know the regional and national status of diseases that can limit the marketing of meat and milk, both nationally and internationally (14). Paratuberculosis is one of the causes of the low development of sheep and goat industries, limiting meat and milk commercialization at national and international levels (14). For 
this reason, it is appropriate to evaluate the extent of the disease. Furthermore, the producers are interested in knowing the infection status of their flocks, in order to implement plans to control and prevent the disease, without ignoring the zoonotic potential of MAP because of its relationship with human Crohn's disease (2, 15-17).

The antecedents of paratuberculosis in small ruminants in Colombia are very rare; there have been reports of paratuberculosis in sheep mainly in the Cundiboyacense highland and the Bogotá Savannah (18-20). The prevalence of paratuberculosis in sheep and goat populations in Colombia is unknown. According to a recent systematic review for Latin America and the Caribbean, in which Colombian studies were included, the prevalence of paratuberculosis in sheep is $16 \%$ at the animal level, and $4.3 \%$ and $3.7 \%$ in goats at the animal and at the flock level, respectively. The prevalence in sheep at the flock level was not reported (21). Unfortunately, there is no official program for prevention and control of paratuberculosis in sheep and goats in Colombia.

The negative productive and reproductive effects of MAP in sheep and goats, the confirmed presence and circulation of MAP in cattle (22-26), the increasing consumption levels of goat milk, lamb, and mutton in Colombia, which in turn increases the potential human exposure to MAP, and the absence of plans, programs, or projects to prevent or control the disease make the initial estimate of the disease prevalence in the primary production centers of sheep and goats in Colombia vey necessary.

The aim of this study was to determine the presence of antibodies against MAP, and to explore the association of individual factors to MAP serological status of sheep and goats in a flock of the premontane rainforest in the department of Antioquia, Colombia.

\section{Materials and methods}

The type of this study is cross-sectional. The flock is located in El Hatillo district of the municipality of Barbosa in the department of Antioquia, Colombia; it is located at 1540 meters above sea level in a premontane rainforest (bh-PM) zone according to the Holdridge life zones system, with an average temperature of $22{ }^{\circ} \mathrm{C}$, an annual rainfall of 1800 $\mathrm{mm}$, and a relative humidity of $80 \%$. The flock was chosen due to its accessibility and availability of records and animals.

Blood samples were collected from all goats and sheep aged over 2 years $(n=59)$ on one flock in October 2014. The inclusion criteria to select the animals participating in the study was the age. Blood samples for blood serum were taken from the jugular vein using Vacuette ${ }^{\circledR}$ tubes of $7 \mathrm{ml}$ without anticoagulant (Greiner Bio-one, Kremsmünster, Austria), and a single 21G x 11/2" caliber needle per animal after local cleaning and disinfection with antiseptic alcohol. After collection, the samples were allowed to stand at room temperature to allow clot retraction. Subsequently, each sample was centrifuged at 2000-2500 rpm for 3-5 minutes to ease the serum extraction. The serum obtained was kept refrigerated until arrival at the Diagnostic Unit of the Facultad de Ciencias Agrarias at the Universidad de Antioquia in Medellin, where it was frozen at $-20{ }^{\circ} \mathrm{C}$ until processed by the ELISA test.

The presence of antibodies against MAP in the blood serum samples was determined by ELISA using a commercial diagnostic kit (IDVet Paratuberculosis Indirect Screening test, Grabels, France). This ELISA kit has a reported sensitivity (Se) of $41.5 \%$ and specificity (Sp) of $99.42 \%$. The test is an M. phlei absorbed ELISA detecting anti-MAP immunoglobulin G (IgG) (27). This ELISA kit was chosen as it displayed the highest overall accuracy of four commercial kits investigated by ROC analysis (27). The kit was used according to the manufacturer's instructions and protocol. Briefly, the samples were diluted 1:12 with dilution buffer 6 on a pre-dilution microplate, and incubated for 45 minutes at $21{ }^{\circ} \mathrm{C} .100 \mu \mathrm{l}$ of the controls and samples were transferred to the ELISA microplates and incubated for 45 minutes at $21{ }^{\circ} \mathrm{C}$. The microplates were washed three times with approximately $300 \mu \mathrm{l}$ of washing solution. The $1 \mathrm{X}$ Conjugate was prepared, and $100 \mu \mathrm{l}$ were distributed into the wells and incubated for 30 minutes at 21 
${ }^{\circ} \mathrm{C}$. The microplates were washed three times with approximately $300 \mu \mathrm{l}$ of washing solution. $100 \mu \mathrm{l}$ of the substrate solution were distributed in all microplates and incubated for 15 minutes at $21^{\circ} \mathrm{C}$ in the dark. Then, $100 \mu$ l of the stop solution were distributed and the optical intensity was read at $450 \mathrm{~nm}$. To establish the ELISA result, the Optical Density $(\mathrm{OD})$ of the sample $\left(\mathrm{OD}_{\text {sample }}\right)$, the mean value of the Positive Control OD $\left(\mathrm{OD}_{\mathrm{PC}}\right)$, and the mean value of the Negative Control OD $\left(\mathrm{OD}_{\mathrm{NC}}\right)$ were determined. Subsequently, the mean value of the $O D_{\mathrm{PC}}$ and the mean value of the $O D_{\mathrm{NC}}$ were obtained. The result obtained with these calculations determined the validity of the test. Each sample was tested only once due to budget limitations. For each sample, the S/P percentage was calculated by the formula $S / P=O D$ sample $-O D_{N C} \times 100 /$ $\mathrm{OD}_{\mathrm{PC}}-\mathrm{OD}_{\mathrm{NC}}$. Animals were assigned a MAP status (positive or negative) according to the kit manufacturer interpretation ('kit-interpretation'), with serum results of $\mathrm{S} / \mathrm{P} \geq 70 \%$ classified as positive.

To explore the association between individual factors and the MAP serological status of sheep and goats, information on breed, age, parity, sex, weight, body condition, and origin of each animal was taken at the time of sample collection.
The study was approved by the Ethics Committee for Animal Experimentation of the University of Antioquia (CEEA, Act 89 of May 29, 2014).

\section{Results and discussion}

The ELISA test did not detect any positive or suspect animal among the 59 analyzed animals (53 goats and 6 sheep).

\section{A. Descriptive analysis of goat's information}

From the 53 goats, $51 \%, 28.3 \%$, and $20.7 \%$ belonged to the breed type Saanen, American Alpine $(\mathrm{AAL})$, French Alpine (FAL), and British Alpine $(\mathrm{BAL})$ and their crossbreeds, respectively. From the 53 goats, $62.3 \%(\mathrm{n}=33)$ and $37.7 \%(\mathrm{n}=20)$ were $\geq 4$ years old and $<4$ years old, respectively. Regarding the origin of the animals, $52.8 \%(\mathrm{n}=$ 28) of the goats was born outside the flock, while $47.2 \%(n=25)$ was born in the flock (Table I).

\section{B. Descriptive analysis of sheep's information}

From the 6 sheep, $50 \%$ belonged to the Black Head Persian breed (BHP), and the other $50 \%$ was camuros and their crossbreeds. Half of the population was $\geq 4$ years old and the other $<4$ years old. Regarding their origin, $50 \%(n=3)$ of sheep was born outside the flock, while the other half was born in the flock (Table I).

Table I. Information of sampled animals for the detection of antibodies against MAP in a premontane rainforest flock in Antioquia, Colombia.

\begin{tabular}{|c|c|c|c|c|}
\hline Variable & $\begin{array}{c}\text { Goats } \\
n=53\end{array}$ & n (\%) & $\begin{array}{c}\text { Sheep } \\
n=6\end{array}$ & n (\%) \\
\hline Breed Type & \begin{tabular}{|l} 
Saanen \\
Crossbreed \\
AAL, FAL, \\
BAL \\
\end{tabular} & $\begin{array}{l}27(51) \\
11(20,7) \\
15(28.3)\end{array}$ & $\begin{array}{l}\text { BHP } \\
\text { Camuro }\end{array}$ & $\begin{array}{l}3(50) \\
3(50)\end{array}$ \\
\hline Age & $\begin{array}{l}\geq 4 \text { years } \\
<4 \text { years }\end{array}$ & $\begin{array}{ll}33 & (62.3) \\
20 & (37.7) \\
\end{array}$ & $\begin{array}{l}\geq 4 \text { years } \\
<4 \text { years }\end{array}$ & $\begin{array}{l}3(50) \\
3(50)\end{array}$ \\
\hline Sex & $\begin{array}{l}\text { Male } \\
\text { Female }\end{array}$ & $\begin{array}{l}8(15) \\
45(85) \\
\end{array}$ & $\begin{array}{l}\text { Male } \\
\text { Female }\end{array}$ & $\begin{array}{l}2(33.3) \\
4(66.7)\end{array}$ \\
\hline Parity & $\begin{array}{l}\geq 4 \\
2-3 \\
1 \\
0\end{array}$ & $\begin{array}{l}21(40) \\
4(7.5) \\
3(5.6) \\
17(32)\end{array}$ & $\begin{array}{l}2 \\
1 \\
0\end{array}$ & $\begin{array}{l}1(25) \\
1(25) \\
2(50)\end{array}$ \\
\hline
\end{tabular}




\begin{tabular}{|c|c|c|c|c|}
\hline Variable & $\begin{array}{l}\text { Goats } \\
n=53\end{array}$ & n $(\%)$ & $\begin{array}{c}\text { Sheep } \\
n=6\end{array}$ & n $(\%)$ \\
\hline Weight & $\begin{array}{l}>40 \mathrm{~kg} \\
30-40 \mathrm{~kg} \\
<30 \mathrm{~kg}\end{array}$ & $\begin{array}{l}15(28.4) \\
24(45.2) \\
14(26.4)\end{array}$ & $\begin{array}{l}>30 \mathrm{~kg} \\
20-30 \mathrm{~kg}\end{array}$ & $\begin{array}{l}2(33.3) \\
4(66.7)\end{array}$ \\
\hline Corporal Condition & $\begin{array}{l}\geq 3.5 \\
3 \\
2.5 \\
2 \\
<2\end{array}$ & $\begin{array}{l}6(11.4) \\
26(49) \\
8(15.1) \\
6(11.3) \\
7(13.2)\end{array}$ & $\begin{array}{l}3.5 \\
3 \\
2.5\end{array}$ & $\begin{array}{l}3(50) \\
2(33.3) \\
1(16.7)\end{array}$ \\
\hline Origin & $\begin{array}{l}\text { External } \\
\text { Internal }\end{array}$ & $\begin{array}{l}28(52.8) \\
25(47.2)\end{array}$ & $\begin{array}{l}\text { External } \\
\text { Internal }\end{array}$ & $\begin{array}{l}3(50) \\
3(50)\end{array}$ \\
\hline $\begin{array}{l}\text { AAL: American Al- } \\
\text { pine, FAL: French } \\
\text { Alpine, BAL: British } \\
\text { Alpine, BHP: Black } \\
\text { Head Persian } \\
\text { breed. }\end{array}$ & & & & \\
\hline
\end{tabular}

\section{Results and discussion}

In the present study, we determined the serological status of antibodies against MAP of a population of 53 goats and 6 sheep belonging to a flock located in a premontane rainforest (bh-PM) in the municipality of Barbosa, Antioquia, Colombia. According to the reviewed national literature, this is the first study reporting the search for antibodies against MAP in a goat population, and the fourth study reporting results in sheep in Colombia, after the studies of Murillo-Rondón (1981), Mogollón et al. (1983), and Mancipe et al. (2009). Consequently, the serological status of goats is the first national report of MAP in this species. The presence of seronegative sheep to MAP contrasts with the reported in previous studies that have found positive animals in the Cundiboyacense plateau $(18,19,20)$. In the department of Antioquia, the presence of paratuberculosis in sheep and goats has been only suspected based on compatible clinical symptoms (Yadi M. Garcia, personal communication, February 15,2015$)$.

Ante-mortem paratuberculosis diagnosis is complicated by the nature of the disease and some limitations of the diagnostic tests. The clinical diagnosis in small ruminants is challenging, the symptoms are vague and nonspecific, and weight loss is present, which also occurs in many other diseases. The disease can be diagnosed by pathology, microbiology (culture and PCR) and immunological methods (ELISA, AGID, complement fixation). The ELISA test, bacterial culture samples, and PCR are the most widely used diagnostic tests. However, none of these methods is highly sensitive, especially during the early stages of the disease (28-31).

The sensitivity and specificity of diagnostic tests vary significantly, and access to clear and reliable information about these features, product evaluations, and systematic comparisons, is difficult. The main reasons are the diversity in study designs of comparison and evaluation, test components, and different pathophysiological states of animals used for diagnosis and evaluation of tests $(9,32)$. These limitations require to adequately define the purpose of the diagnosis, in order to apply the most appropriate diagnostic procedures $(29,33,34)$.

The selection of ELISA in this study was based on previous studies (35-37). As the culture of sheep strains of MAP using culture media (Herrold's egg yolk medium) has been extremely difficult to perform, and the cost of PCR exceeds the study budget, these tests were not performed. Among the an- 
tibody tests, ELISA is more sensitive than the AGID and CFT $(38,39)$; its performance is similar in cattle, sheep, and goats $(40,41)$, and can be used with comparable sensitivity for either milk or serum samples. AGID test is considered less sensitive than ELISA and CFT (42). Since a strong humoral response does not occur until the later stage of paratuberculosis, the sensitivity of these three tests is the highest for animals with lepromatous lesions, those with clinical symptoms, or those that shed large numbers of bacteria (43). Therefore, the main limitation of these antibody tests is their inability to identify animals in early infection stages.

The absence of seropositive results in ELISA is surprising compared to the initial expectations, and could be explained by the low circulation of MAP in the flock and in the studied region. No animal was observed displaying clinical signs of paratuberculosis at the time of sampling. However, it is possible that some animals may have been infected, but these animals were in the subclinical stage of the disease, in which case, ELISA would deliver very low seroprevalence results (18). Another possibility is that many of the results correspond to false negatives due to the low sensitivity of the ELISA test; ELISA sensitivities of $63-84 \%$ and 16$44 \%$ in asymptomatic goats and sheep, respectively, have been reported in other countries (29, 44). Additionally, the success of serological tests like ELISA in terms of sensitivity resides in the degree of animal response against the test, the number of sampled animals, and the prevalence of the disease in the flock (44). The sensitivity of ELISA varies over a wide range: values of $<10 \%$ (during the subclinical stage of the disease) and up to $90 \%$ (usually in advanced clinical cases) can be found, indicating a variability of the test due to the clinical stage and the distribution of the disease (44).

The absence of seropositive animals in ELISA is also surprising taking into consideration the individual factors of the animals, e.g., higher population of goats than sheep. Goats are naturally less resistant to paratuberculosis compared to sheep and cattle (13), and interspecies transmission in herds with extensive production systems is more common (2, 45). The diversity of breed type is also striking be- cause, although no studies have thoroughly examined if the different breeds of sheep are more or less susceptible to paratuberculosis, some previous studies have reported that local breeds of sheep (Nilagiri and Sandyno) in India were more susceptible than exotic breeds (Dorset). In New Zealand, a significantly higher percentage of clinical paratuberculosis was observed in Merino or Merino Romney crossbreed sheep compared to Romney sheep $(46,47)$.

The advanced age (mostly $\geq 4$ years old) and sex (mostly female) are also surprising because, although no study of the relationship between age or sex and susceptibility to MAP infection in sheep has been published (4), previous studies indicate that the paratuberculosis is commonly observed in sheep in the age group from 4 months to 10 years, being females more susceptible than males (46, 48). Regarding parity (majority $\geq 4$ and 0 births for goats and sheep, respectively), there are no reports of its relationship with the presence of antibodies against MAP in small ruminants. However, a previous study in dairy cows concluded that the highest probability of finding a positive result in the ELISA test was in cows with parity $\geq 5$, which agrees with the chronic nature of the infection which implies that cows must age enough to show the symptoms of the disease (49).

Low body condition (several animals with body conditions $\leq 2.5$ ), the lack of hygiene that exposes younger animals to feces from older animals, milk contamination, and inadequate feed supply are some of the conditions that predispose MAP infection (50). Many of the animals in both species came from external flocks. In goats, the seroprevalence of MAP has been associated with high replacement rates (51).

\section{Conclusion}

In this study, antibodies against MAP were not found in a flock of sheep and goats located in a premontane rainforest (bh-PM) in Barbosa, Antioquia, Colombia. Several factors, such as low circulation of MAP in the flock and in the region, animals in the subclinical phase of the disease at the moment of sampling, and false negative results due 
to the low sensitivity of the ELISA test may explain the serological status of the sampled animals. It is necessary to continue with similar studies in other flocks of the region and the country to determine the actual status of infection in small ruminants in Colombia.

\section{Acknowledgements}

Departamento de Formación Académica de Haciendas de la Facultad de Ciencias Agrarias, UdeA; Estrategia de Sostenibilidad CODI 2013-2014 de la UdeA; Colciencias Young Researches (semilleros) (convocatoria 617 de 2013), Walter Hernández, Leonardo Navarro, and Jesús Moreno for their support collecting samples and information.

\section{References}

(1) Chiodini R. Abolish Mycobacterium paratuberculosis strain 18. Clin Microbiol Rev. 1993; 31: 1958-1986.

(2) Kruze J., Salgado M., Collins M. Paratuberculosis en rebaños caprinos chilenos. Arch. Med. Vet. 2007; 39: 147-152. DOI: http:// doi.org/10.4067/S0301-732X2007000200008.

(3) Clarke CJ. The pathology and pathogenesis of paratuberculosis in ruminants and other species. J. Comp. Pathol. 1997; 116: 217261. DOI: http://doi.org/10.1016/S0021-9975(97)80001-1.

(4) Begg D., Whittington R. Paratuberculosis in Sheep. En: Behr MA., Collins DM. Paratuberculosis Organism, Disease, Control. 1ra ed. Oxfordshire, UK: CAB International. 2010: 157-168. DOI: http://doi.org/10.1079/9781845936136.0157.

(5) Robbe-Austerman S. Control of paratuberculosis in small ruminants. Vet. Clin. North Am. Food Anim. Pract. 2011; 27: 609620. DOI: http://doi.org/10.1016/j.cvfa.2011.07.007.

(6) Clarke CJ., Little D. The pathology of ovine paratuberculosis: gross and histological changes in the intestine and other tissues. J. Comp. Pathol. 1996; 114: 419-437. DOI: http://doi.org/10.1016/ S0021-9975(96)80017-X.

(7) Juste RA., Perez V. Control of Paratuberculosis in Sheep and Goats. Vet. Clin. North Am. Food Anim. Pract. 2011; 27: 127138. DOI: http://doi.org/10.1016/j.cvfa.2010.10.020.

(8) Anonymous. The economic impact of OJD infection on sheep farms. Meat and Livestock Australia. 2005. Disponible en: http://www.animalhealthaustraliacom.au/wp-content/ uploads/2011/04/The-economic-impact-of-OJD.pdf.

(9) Djønne B. Paratuberculosis in Goats. En: Behr MA, Collins DM, editores. Paratuberculosis Organism, Disease, Control. 1ra ed. Oxfordshire, UK: CAB International; 2010:169-178. DOI: http:// doi.org/10.1079/9781845936136.0169.

(10) Storset AK., Hasvold HJ., Valheim M., Brun-Hansen H., Berntsen G. Subclinical paratuberculosis in goats following experimental infection. An immunological and microbiological study. Vet. Immunol. Immunopathol. 2001; 80: 271-287. DOI: http://doi. org/10.1016/S0165-2427(01)00294-X.
(11) Kostoulas P., Leontides L., Billinis C. The association of sub-clinical paratuberculosis with the fertility of greek dairy ewes and goats varies whit parity. Prev Vet Med. 2006; 74: 226-238. DOI: http://doi.org/10.1016/j.prevetmed.2005.12.001.

(12) Angelidou E., Kostoulas P., Leontides L. Flock-level factors associated with the risk of Mycobacterium avium subsp. paratuberculosis (MAP) infection in Greek dairy goat flocks. Prev Vet Med. 2014; 117: 233-41. DOI: http://doi.org/10.1016/j.prevetmed.2014.09.002.

(13) Stewart D., Vaughan J., Stiles P. A long-term bacteriological and immunological study in Holstein- Friesian cattle experimentally infected with Mycobacterium avium subsp. Paratuberculosis and necropsy culture results for Holstein- Friesian cattle, merino sheep and angora goats. Vet. Microbiol. 2007; 122: 83-96. DOI: http://doi.org/10.1016/j.vetmic.2006.12.030.

(14) Castellanos MJ., Rodríguez CJ., Toro CW. Agenda de investigación y desarrollo tecnológico para la cadena cárnica ovino caprina en Colombia. MADR-Tecnos. 2010.

(15) De Juan L., Mateos A., Domínguez L., Sharp J., Stevenson K. Genetic diversity of Mycobacterium avium subspecies paratuberculosis isolates from goats detected by pulsed-field gel electrophoresis. Veterinary Microbiology. 2005: 106: 249-257. DOI: http://doi.org/10.1016/j.vetmic.2004.12.013.

(16) Over K., Crandall P., O'Bryan C., Ricke C. Current perspectiveson Mycobacterium avium subsp. paratuberculosis Johne's disease, and Crohn's disease: a review. Crit. Rev. Microbiol. 2011; 37:141-156. DOI: http://doi.org/10.3109/104084 1 X.2010.532480.

(17) Sechi L., Mura M., Tanda F., Lissia A., Solinas A, et. al. Identification of Mycobacterium avium subsp. paratuberculosis in biopsy specimens from patients with Crohn's disease identified by in situ hybridization. J. Clin. Microbiol. 2001; 39: 4514-4517. DOI: http://doi.org/10.1128/JCM.39.12.4514-4517.2001.

(18) Mancipe L., Sánchez J., Rodríguez G. Estudio de la paratuberculosis en un rebaño de ovinos de la sabana de Bogotá mediante la utilización de tres técnicas diagnósticas. Rev. Med. Vet. 2009; 18: 33-51.

(19) Mogollón G., De Galvis A., Tovar L., Murillo N., Mosses N. Prevalencia de paratuberculosis ovina en el altiplano cundiboyacense. Revista ICA. 1983; 18: 479-484

(20) Murillo-Rondón LE. Prevalencia serológica de la paratuberculosis ovina por la prueba de fijación de complemento. Tesis de pregrado, Facultad de Medicina Veterinaria y Zootecnia, Universidad Nacional de Colombia, Bogotá. 1981.

(21) Fernández-Silva JA., Correa-Valencia NM., Ramírez-Vásquez N. Systematic review of the prevalence of paratuberculosis in cattle, sheep, and goats in Latin America and the Caribbean. Trop Anim Health Prod. 2014; 46(8): 1321-40. DOI: http://doi.org/10.1007/ s11250-014-0656-8.

(22) Fernández-Silva JA., Abdulmawjood A., Akineden O., Bulte M. Serological and molecular detection of Mycobacterium avium subsp. paratuberculosis in cattle of dairy herds in Colombia. Trop Anim Health Prod. 2011; 43: 1501-1507. DOI: http://doi. org/10.1007/s11250-011-9833-1. 
(23) Fernández-Silva JA., Abdulmawjood A., Bulte M. Diagnosis and Molecular Characterization of Mycobacterium avium subsp. paratuberculosis from dairy cows in Colombia. Vet Med Int. 2011; $1: 29$.

(24) Ramírez-Vásquez N., Rodríguez B., Fernández-Silva JA. Diagnóstico clínico e histopatológico de paratuberculosis bovina en un hato lechero en Colombia. MVZ. 2001; 16(3): 2742-2753.

(25) Ramírez-García R., Maldonado-Estrada JG. Detection of macrophages infected with Mycobacterium avium subspecies paratuberculosis in a cow with clinical stage IV of the disease. A case report. Rev Colomb Cienc Pecu. 2013; 26: 219-225.

(26) Zapata MM., Arroyave O., Ramírez R., Piedrahita C., Rodas JD. Identification of Mycobacterium avium subspecies paratuberculosis by PCR techniques and establishment of control programs for bovine paratuberculosis in dairy herds. Rev Colomb Cienc Pecu. 2010; 23: 17-27.

(27) Fry MP., Kruze J., Collins MT. Evaluation of four commercial enzyme-linked immunosorbent assays for the diagnosis of bovine paratuberculosis in Chilean dairy herds. I Vet Diagn Investig. 2008;20(3): 329-32. DOI: http://doi. org/10.1177/104063870802000311.

(28) Clark DL., Koziczkowski JJ., Radcliff RP., Carlson RA., Ellingson JL. Detection of Mycobacterium avium subspecies paratuberculosis: comparing fecal culture versus serum enzyme-linked immunosorbent assay and direct fecal polymerase chain reaction. Journal of Dairy Science. 2008;91: 2620-2627. DOI: http://doi. org/10.3168/jds.2007-0902.

(29) Nielsen SS., Toft N. Ante-mortem diagnosis of paratuberculosis: a review of accuracies of ELISA, interferon-gamma assay and faecal culture techniques. Vet Microbiol. 2008; 2129:217-235. DOI: http://doi.org/10.1016/j.vetmic.2007.12.011.

(30) Stevenson K. Diagnosis of Johne's disease: current limitations and prospects. Cattle Practice. 2010b; 18: 104-109.

(31) Bauman CA., Jones-Bitton A., Jansen J., Kelton D., Menzies P. Evaluation of fecal culture and fecal RT-PCR to detect Mycobacterium avium ssp. paratuberculosis fecal shedding in dairy goats and dairy sheep using latent class Bayesian modeling. BMC veterinary Research. 2016; 12: 212. DOI: http://doi.org/10.1186/ s12917-016-0814-5.

(32) Nielsen SS., Toft N. A review of prevalence of paratuberculosis in flocked animals in Europe. Preventive Veterinary Medicine. 2009; 88:1-14. DOI: http://doi.org/10.1016/j.prevetmed.2008.07.003.

(33) Nielsen SS. Immune-based Diagnosis of Paratuberculosis. In: Behr, M.A., Collins, D.M. (Eds.), Paratuberculosis: Organism, Disease, Control. CAB International, Oxfordshire. 2010; 284-293. DOI: http://doi.org/10.1079/9781845936136.0284.

(34) Collins MT., Gardner IA., Garry FB., Roussel AJ., Wells SJ. Consensus recommendations on diagnostic testing for the detection of paratuberculosis in cattle in the United States. J. Am. Vet. Med Assoc. 2006; 229: 1912-1919. DOI: http://doi.org/10.2460/javma.229.12.1912.

(35) Collins DM., Hilbink F., West DM. Investigation of Mycobacterium paratuberculosis in sheep by faecal culture, DNA char- acterization and the polymerase chain reaction. Vet Rec. 1993; 133(24): 599.

(36) De Lisle GW., Collins DM., Huchzermeyer HF. Characterization of ovine strains of Mycobacterium paratuberculosis by restriction endonuclease analysis and DNA hybridization. Onderstepoort J Vet Res. 1992; 59(2): 163.

(37) Shulaw WP., Bech-Nielsen S., Rings DM., Getzy DM., Woodruff TS. Serodiagnosis of paratuberculosis in sheep by use of agar gel immunodiffusion. Am / Vet Res. 1993; 54: 13-19.

(38) Cocito CP., Coene M., De Kesel M., Poupart P., Vannuffel P. Paratuberculosis. Clin Microbiol Rev. 1994; 7: 328-345. DOI: http://doi.org/10.1128/CMR.7.3.328.

(39) Collins MT. Diagnosis of paratuberculosis. Vet Clin North Am. Food Anim Pract. 1996; 12: 357-371. DOI: http://doi. org/10.1016/S0749-0720(15)30411-4.

(40) Burnside DM., Rowley BO. Evaluation of an enzyme-linked immunosorbent assay for diagnosis of paratuberculosis in goats. Am J Vet Res. 1994; 55: 465-466.

(41) Dubash K., Shulaw WP., Bech-Nielsen S., Stills HF., Slemons RD. Evaluation of an agar gel immunodiffusion test kit for detection of antibodies to Mycobacterium paratuberculosis in sheep. J Am Vet Med Assoc. 1996; 208: 401-403

(42) Nielsen SS., Nielsen KK., Huda A., Condron R., Collins MT. Diagnostic techniques for paratuberculosis. In: Bulletin of the international dairy federation. IDF. 2001; 362: 5-17.

(43) Ahmed IM. Serodiagnosis of Johne's disease by indirect ELISA in ovine. Iraqi Journal of Veterinary Sciences. 2010; 24: 41-43.

(44) Sergeant E., Marshall D., Eamens J., Kearns C., Whittington RJ. Evaluation of an absorbed ELISA and an agar-gel immuno-diffusion test for ovine paratuberculosis in sheep in Australia. Prev. Vet. Med. 2003; 61: 235-248. DOI: http://doi.org/10.1016/j.prevetmed.2003.08.010.

(45) Holstad G., Sigurðardóttir Ó., Storset A., Tharaldsen J., Nyberg O., Schönheit J., Djønne B. Description of the infection status in a Norwegian cattle herd naturally infected by Mycobacterium avium subsp. paratuberculosis. Acta Vet. Scand. 2005; 46: 4556. DOI: http://doi.org/10.1186/1751-0147-46-45.

(46) Hemalatha S., Parimal R., Purushothaman V., lyue M. Paratuberculosis in different breeds of sheep: A retrospective study of cases. Int J Mycobacteriol. 2013; 2: 166-170. DOI: http://doi. org/10.1016/j.ijmyco.2013.07.002.

(47) Morris CA., Hickey SM., Henderson HV. The effect of Johne's disease on production traits in Romney, Merino and Merino $\times$ Romney-cross ewes. N Z Vet J. 2006; 54: 204-209. DOI: http:// doi.org/10.1080/00480169.2006.36698.

(48) Tripathi BW., Paritra NS. Status of paratuberculosis in goats - a 5 years study based on postmortem cases. Indian J. Vet. Pathol. $1999 ; 23: 79-80$.

(49) Jakobsen MB., Alban L., Nielsen SS. A cross-sectional study of paratuberculosis in 1155 Danish dairy cows. Prev. Vet. Med. 2005; 46: 15-27. DOI: http://doi.org/10.1016/S01675877(00)00138-0.

(50) Radostits OM., Gay CC., Hinchcliff KW., Constable PD. Diseases associated with bacteria. En: Rodenhuis J, Ball E, editores. Veterinary Medicine: a Textbook of the Diseases of Cattle, Horses, 
Sheep, Pigs and Goats, 10 ed. USA: Saunders: Elsevier; 2007. p. 1017-1044.

(51) Mainar-Jaime R., Vázquez-Boland J. Factors associated with seroprevalence to Mycobacterium paratuberculosis in small-ruminant farms in the Madrid region (Spain). Prev. Vet. Med. 1998; 34: 317-327. DOI: http://doi.org/10.1016/S0167-5877(97)00091-3. 